\title{
Action on climate change: no time to delay
}

\author{
Rosalie E Woodruff, Anthony J McMichael and Simon Hales \\ Global warming is real, so what are we going to do about it, who will do it, and when?
}

$\longrightarrow$ limate change is now widely acknowledged as the greatest environmental threat that human civilisation faces. ${ }^{1}$ During 2005 there was a perceptible shift in scientific assessment of the consequences of increasing greenhouse gas accumulation in Earth's atmosphere. Normally cautious climate scientists went on record with warnings that potentially unstoppable "runaway" climate change is now becoming a real risk. The faster than expected melting of Greenland ice, slowing of ocean currents, and possible reversal of terrestrial ecosystems (see Box) from carbon "sinks" to net sources of carbon dioxide emissions are prominent examples of non-linear change. Impacts of climate change on the biosphere are now clear, including melting of polar ice, shrinking of glaciers, and shifts in the biotic cycles and behaviours of birds, insects and plants. International assessments have sounded serious environmental alarms before, but the emerging evidence on climate change now brings an unprecedented urgency to policy debates. In the past year, public (and belatedly, political) discussion in Australia has moved on from questioning whether there is a human influence on climate change. The questions now being framed are what we should be doing about this, and who should be responsible?

\section{A $2^{\circ} \mathrm{C}$ limit to avoid dangerous climate change}

Largely unchecked greenhouse gas emissions to date have already committed future societies to temperature increases. British Prime Minister, Tony Blair, commissioned a conference in Exeter in 2005 to answer the question "What level of greenhouse gases in the atmosphere is self-evidently too much?". ${ }^{2}$ A limit in global mean surface temperature to $2^{\circ} \mathrm{C}$ above preindustrial times has since been recognised, in many ways, as a reasonably close marriage of pragmatism and science. Many small ecosystems in Australia are likely to be lost or severely damaged with temperature increases of $1-2^{\circ} \mathrm{C}$ (including the Great Barrier Reef, Kakadu, the Alpine zone, and the World Heritage rainforest area $)^{3}$ as plants and animals are unable to adapt or migrate. Above $2^{\circ} \mathrm{C}$, agricultural yields are predicted to fall, several billion people would experience increased water stress, additional hundreds of millions may go hungry, sea level rise may displace millions from coasts, and infectious disease risks multiply.

Achieving a global average $2^{\circ} \mathrm{C}$ limit would result in slightly different temperature increases across Australia (lower than this in the south and greater warming towards the centre of the continent). Compared with the estimated future impacts of the current emissions trajectory, a $2^{\circ} \mathrm{C}$ limit would substantially reduce the annual heat-related mortality in Australia, as well as the southward extension of some mosquito-borne diseases. ${ }^{4}$

\section{The immediate priority: reducing emissions}

Achieving the widely proposed $2^{\circ} \mathrm{C}$ ceiling on global temperature increases means a rapid transition from fossil fuels to environmentally sound energy sources — within decades. ${ }^{5}$ Delays beyond that will necessitate far deeper and more rapid emission cuts to achieve

\section{Glossary}

Ecosystem: A functional unit of interdependent organisms, together with their physical environment, linked together through nutrient cycling and energy flow. An ecosystem can be any size - a pond, field, forest, or Earth's biosphere - but it always functions as a whole unit.

Fossil fuels: Fuels such as coal, oil and gas made by the decomposition of ancient plant and animal remains which give off carbon dioxide when burned.

Geosequestration: Sequestration is the storage of greenhouse gases from the atmosphere by plants or technological measures. Plants absorb carbon dioxide, release the oxygen and store the carbon in the soil. Geosequestration refers to the storage of carbon dioxide in underground reservoirs (such as old oil or gas wells).

Greenhouse gases: Molecules (such as carbon dioxide and methane) that warm the atmosphere because they absorb some of the radiation that is emitted from the surface of Earth.

Heat-island effect: Dark, dense materials (such as roof tiles or asphalt) absorb more heat from the sun than surrounding objects, and release the heat into houses and city areas in the evenings. In an urban heat island the temperature of a city can be $2-10^{\circ} \mathrm{C}$ higher than the surrounding rural area. The larger and more populationdense an urban area, the more pronounced is the heat-island effect. Landscape and housing design, vegetation, building spacing and paving materials all contribute to the heat-island effect.

this goal. The inertia of the socioeconomic system means that we cannot expect to be able to turn it around more quickly in future than we can now. Further, recent research by major Australian businesses (including BP Australia, Westpac, Insurance Australia Group, and Origin Energy) indicates there will be economic disadvantages if we delay. If early action is taken, a $60 \%$ reduction in Australian greenhouse gas emissions by 2050 is possible while still maintaining strong economic growth (with real gross domestic product [GDP] averaging $2.1 \%$ per year). Compared with this, postponing action to 2022 would result in lower real GDP growth of an average $0.2 \%$ per year, through to $2050 .^{6,7}$

Climate change is a global problem that requires responses at multinational as well as national levels. The European Union plans to reduce its greenhouse gas emissions in line with a global $2^{\circ} \mathrm{C}$ target, and is investing in infrastructure, technologies and social policies. Sweden has announced a policy of non-reliance on oil by $2020 .^{8}$ In contrast, climate change mitigation policy in Australia still lags behind Europe, and our government has not yet set a national greenhouse gas emissions reduction target beyond 2012 .

Procrastinating on reducing emissions means we are betting on future technological improvements to make the transition as seamless as possible. So far, there is no simple technological fix on the horizon to cure an overheating planet. The benefits of geosequestration (piping carbon dioxide emissions from power stations into storage wells), for example, have still to be proven in terms of efficacy, affordability and safety. It is far more likely that, 


\section{EDITORIALS}

as with preventive strategies for other major public health problems (such as smoking cessation or obesity reduction), we will need a "portfolio" approach to reducing emissions.

While the full benefits from global greenhouse gas mitigation will only be experienced by future generations, the ancillary benefits of local emissions reduction policies would have immediate health benefits. For example, air pollution from motor vehicles caused an estimated 900-2000 early deaths in Australia in the year 2000 , entailing direct costs of between $\$ 1.1$ and $\$ 2.6$ billion. A $50 \%$ reduction in vehicle-related emissions in the combined Sydney and Melbourne regions could avert 300-500 premature deaths per year from air pollution in those cities. ${ }^{4}$ Less car dependence (with a shift to public transport, walking and bike riding) would presumably also have substantial health and social benefits, through increased physical activity and social interaction.

\section{Adaptation measures}

It has been widely assumed that wealthy human societies will be able to buffer themselves from the more severe impacts of climate change, at least initially. However, events such as Hurricane Katrina and the European heatwave have shown that societies everywhere are vulnerable to extreme and unpredictable weather. In the late summer of 2003, an unprecedented heatwave in Northern Europe led to several tens of thousands of premature deaths. ${ }^{9}$ Elderly people were most vulnerable, as thermoregulatory ability usually decreases with age. ${ }^{10}$ The main contributing factor to this is reduced physical activity, leading to lower muscle strength, sweating capacity and cardiovascular reserve, and to lower cardiovascular stability. Drugs that affect body fluid balance, vasodilator activity and cardiac function are potentially harmful during extreme heat events.

We know much more about the population-level risks that contribute to increased mortality during heatwaves. People in urban and suburban regions typically have far higher rates of mortality than rural regions. In France, many nursing homes were not air-conditioned, hospitals were understaffed, and families were holidaying (and hence unavailable to support elderly or mentally ill relatives) during what would usually have been a mild summer holiday period. ${ }^{11}$ Social isolation has also been linked to increased risk of death during heatwaves in the United States. ${ }^{12}$

The Australian Government has focused its policy development on identifying the risks and vulnerabilities of sectors to adapting to climate change. ${ }^{7}$ Health departments in several Australian states have commissioned studies of climate change adaptation needs: strategies, such as heatwave forecasting systems and associated directives for workplaces and nursing homes, and alerts for general practitioners, are now in the process of being developed. Details of adaptive strategies to reduce the impact of climate change will be local and context-dependent, although much can be generalised from experiences elsewhere. To support policy, we need more evidence about local conditions that modify heatwaves (such as the heat-island effect, household design to reduce heat retention, and social connectedness). We know that many bacteria (such as salmonellae) are sensitive to climatic conditions. It is less clear how the changing climate will interact with land use and social practices in a particular region to influence the vector, host (eg, domestic or native animal) and pathogen transmission routes for water-borne and food-borne diseases.

We are beginning to understand the challenge that humaninduced climate change poses for us, in terms of the likely impacts on humans. Anticipatory and precautionary adaptation is more effective and less costly than last-minute emergency adaptation or retrofitting. ${ }^{13}$ Even so, relying on incremental adaptation to lessen the evolving risks to health is as inappropriate as progressive multiplication of the number of defibrillator stations in a society undergoing an uptrend in coronary heart disease mortality. In the best traditions of public health, the focus must be on primary prevention - global greenhouse gas abatement. Individuals, families and communities should contribute to the collective effort, but the issue is so large in scale and so systemic in nature that only government-led mitigation can ensure that climate change is slowed and, hopefully, arrested.

\section{Author details}

Rosalie E Woodruff, PhD, MPH, Postdoctoral Fellow ${ }^{1}$ Anthony J McMichael, FACOM, MB BS, PhD, Director ${ }^{1}$ Simon Hales, MB BChir, MPH, PhD, Senior Research Fellow ${ }^{2}$

1 National Centre for Epidemiology and Population Health,

Australian National University, Canberra, ACT.

2 Housing and Health Research Programme, Wellington School of Medicine and Health Sciences, University of Otago, Wellington,

New Zealand.

Correspondence: rosalie.woodruff@anu.edu.au

\section{References}

1 King DA. Climate change science: adapt, mitigate, or ignore? Science 2004; 303: 176-177.

2 Hadley Centre for Climate Prediction and Research. Avoiding dangerous climate change. Conference 2005; Feb 1-3; Exeter, UK. Proceedings available at: http:// wuw.stabilisation2005.com/ (accessed May 2006).

3 Warren R. Impacts of global climate change at different annual mean global temperature increases. In: Schellnhuber $\mathrm{HJ}$, editor. Avoiding dangerous climate change. Cambridge: Cambridge University Press, 2006: 93-132.

4 Woodruff RE, Hales S, Butler C, McMichael AJ. Climate change health impacts in Australia: effects of dramatic $\mathrm{CO}_{2}$ emission reductions. Canberra: Australian Conservation Foundation and the Australian Medical Association, 2005: 44 Available at: http://www.acfonline.org.au/uploads/res_AMA_ACF_Full_ Report.pdf (accessed May 2006).

5 Keller K, Hall M, Kim SR, et al. Avoiding dangerous anthropogenic interference with the climate system. Clim Change 2005; 73: 227-238.

6 Preston $\mathrm{BL}$, Jones RN. Climate change impacts on Australia and the benefits of early action to reduce global greenhouse gas emissions: a consultancy report for the Australian Business Roundtable on Climate Change. Aspendale, Vic: CSIRO, 2006. Available at: http://www.cmar.csiro.au/ (accessed May 2006).

7 Australian Government Department of the Environment and Heritage. Climate change: risk and vulnerability. Promoting an efficient adaptation response in Australia - final report, March 2005. Report to the Australian Greenhouse Office, Department of the Environment and Heritage, by The Allen Consulting Group. Available at: http://wnw.greenhouse.gov.au/impacts/publications/risk-vulnerability.html (accessed May 2006).

8 Sahlin M (Minister for Sustainable Development). Sweden first to break dependence on oil! New programme presented. Available at: http://www.sweden.gov.se/ $\mathrm{sb} / \mathrm{d} / 3212 / \mathrm{a} / 51058$ (accessed May 2006).

9 World disasters report. 2004. Geneva: International Federation of Red Cross and Red Crescent Societies, 2004.

10 Havenith G. Temperature regulation, heat balance and climatic stress. In: Kirch W, Menne B, Bertollini R, editors. Extreme weather events and public health responses. WHO Regional Office Europe. Copenhagen: Springer-Verlag, 2005.

11 Meusel D, Menne B, Kirch W, Bertollini R and the Bratislava Collaborating Group. Public health responses to extreme weather and climate events - a brief summary of the WHO meeting on this topic in Bratislava on 910 February 2004. J Public Health 2004; 12: 371-381.

12 Basu R, Samet JM. Relation between elevated ambient temperature and mortality: a review of the epidemiologic evidence. Epidemiol Rev 2002; 24: 190-202.

13 Watkiss P, Downing T, Handley C, Butterfield R. The impacts and costs of climate change. Commissioned by the European Commission Directorate-General Environment. ENV C.2/2004/0088. Stockholm: AEA Technology Environment, 2005. Available at: http://ec.europa.eu/comm/ environment/climat/pdf/final_report2.pdf (accessed May 2006). 